\title{
Effect of Intercropping System on the Quality and Quantity of Runner Bean (Phaseolus coccineus $\mathrm{L}$.)
}

\author{
Silvia Brîndușa HAMBURDĂ*, Gabriel Ciprian TELIBAN, \\ Neculai MUNTEANU, Vasile STOLERU
}

\author{
University of Agricultural Sciences and Veterinary Medicine "Ion Ionescu de la Brad" Iaşi, \\ Faculty of Horticulture, Department of Vegetable Growing, 3 Mihail Sadoveanu Alley, 700490, Iaşi, \\ Romania; silviah@uaiasi.ro (*corresponding author); teliban_gabriel_ciprian@yahoo.com; nmunte@uaiasi.ro; vstoleru@uaiasi.ro
}

\begin{abstract}
Field experiments were conducted two consecutive years, in order to investigate runner bean (Phaseolus coccineus L.) cultivated in pure crop system and in intercropping system. To achieve the desired aim, we set the following objectives: study of runner bean plant phenology, study of assimilating pigments content in the runner bean leaves, agro productivity study of runner bean crop, yield of runner bean crop, study of chemical composition of runner bean dry seeds. The studied experimental factor was the trellis system with six variants: (V1) - trellis, with double rows, on individual string, (V2) - trellis, with a single row, on individual string, (V3) - trellis, in a single row, on synthetic net (17 cm mesh), (V4) - intercropping with common maize plants, (V5) - intercropping with sunflower plants, (V6) - intercropping with Jerusalem artichoke plants. Runner bean yield ranged from $3,610 \mathrm{~kg} \mathrm{ha}^{-1}$ (V2) to $1,684 \mathrm{~kg} \mathrm{ha}^{-1}$ (V6) (first year) and from $3,170 \mathrm{~kg} \mathrm{ha}^{-1}$ (V2) to $1,189 \mathrm{~kg} \mathrm{ha}^{-}$ ${ }^{1}$ (V6) (second year). Runner bean dry seeds contain: crude protein $22.65 \%$ (V6) - 25.47\% (V3), crude fat 1.91\% (V6) - 2.16\% (V4), crude fibre 5.41\% (V4) - 5.81\% (V5) and nitrogen free extractive substances $62.11 \%(\mathrm{~V} 3)-64.92 \%$ (V4). The best variant of trellis for runner bean crop was the single row trellis system on individual string and the best intercropping system was intercropping with sunflower.
\end{abstract}

Keywords: chemical composition, chlorophyll content, crop systems, grain yield, phenotypic evaluation

\section{Introduction}

Runner bean (Phaseolus coccineus L.) is a herbaceous, outcrossing species, propagated, usually, by seeds (Popa, 2010). In the centre of origin (Mexico and Central America) it is perennial, while in temperate conditions (including Romania), it behaves as an annual species, because the plants, including the root system, do not withstand at low temperatures during wintertime (Rodiňo et al., 2007; Labuda, 2010; Popa, 2010). As a cultivated plant, $P$. coccineus is on the third place, as importance, worldwide, in the Phaseolus group, after P. vulgaris and P. lunatus (Santalla et al., 2004; Rodriguez, 2013), but in Romania it is on the second place, being well known and sometimes being confused with the common bean (Popa, 2010). Being a vegetable species of warm and humid climate, under the forest steppe conditions from Romania, the crop falls under soil drought, atmospheric drought, as well as excessive high temperatures (Popa, 2010).

Therefore, in order to achieve efficient and stable yields, it is necessary to develop a cultivation system in which, through technological practices, unfavourable environmental conditions can be corrected (Hamburdă et al., 2013). These practices should also provide a trellis support in a cheap and efficient culture system for the climbing forms. Such a system of cultivation could be represented by interleaving runner bean plants with other crops, which is the "intercropping" system (Hamburdă et al., 2014).

Intercropping is known for thousands of years and is the system in which, on the same land and in the same time, two or more species are cultivated (Ofori and Stern, 1987; Anil et al., 1998). This culture system provides mutual favourable conditions for the species that are grown (Mousavi and Eskandari, 2011). The mutual favourability of the conditions is appreciated by a better plant growth and development, a superior quantitatively and qualitatively yield and a higher economic efficiency. Moreover, in the ecosystem, intercropping ensures the preservation and improvement of microorganisms' diversity, useful flora and fauna, which, frequently, have a positive impact on crop yields (Vandermeer, 1995; Butnariu et al., 2014; Hamburdă et al., 2015).

In terms of phenology, it is known that runner bean has a relatively long growing season, compared to common bean, reaching up to 130-140 days (Hadjichristodoulou, 1990; Popa, 2010; Munteanu et al., 2013). The yield amount, just like its quality, is conditioned by genotype, environment and interaction 
614

between these factors (Labuda, 2010). For runner bean, as well as other species of the same group, the amount of yield is directly determined by the number of flowers, fruits and seeds per plant and these are correlated with the photosynthetic activity of the plant, in accordance with the environmental conditions (Labuda, 2010).

Runner bean food value is determined by complex chemical composition, with nutritional, energetic, catalytic and mineralizing value (Aremu et al., 2010; Labuda, 2010; Popa, 2010). Vegetable products of this species are sources of complex carbohydrates, protein and dietary fibre, having significant amounts of vitamins and minerals and high energetic value (Tharanathan and Mahadevamma, 2003). Protein contents in dried grains range from $17 \%$ to $40 \%$, contrasting with $7-13 \%$ of cereals, and being equal to the protein contents of meats (1825\%) (Genovese and Lajolo, 2001; De Almeida Costa et al., 2006).

The purpose of this paper was to present the behaviour of runner bean in a pure crop system and in intercropping system, with common maize (Zea mays L.), sunflower (Helianthus annuus L.) and Jerusalem artichoke (Helianthus tuberosus L.). To achieve the desired aim, we set the following objectives: study of runner bean plant phenology; study of assimilating pigments content in the runner bean leaves; agro productivity study of runner bean crop; yield of runner bean crop; study of chemical composition of runner bean dry seeds (quality of the harvest).

\section{Materials and Methods}

\section{Location and experimental conditions}

The experiment was organized during two consecutive years (2014 and 2015) in the experimental field of the vegetable research laboratory of the Adamachi Experimental Station at the University of Agricultural Sciences and Veterinary Medicine (UASVM) Iasi, located in North-Eastern Romania $\left(47^{\circ} 10^{\prime} 43^{\prime \prime} \mathrm{N}\right.$ and $\left.27^{\circ} 37^{\prime} 14^{\prime \prime} \mathrm{E}\right)$. The climate is temperate continental, with an average annual temperature of $9.6^{\circ} \mathrm{C}$ $\left(49.3^{\circ} \mathrm{F}\right)$ and a total average rainfall of $521 \mathrm{~mm}$ per year. In 2014 (during January-August) was recorded $11.9{ }^{\circ} \mathrm{C}$ temperature, $70.5 \%$ humidity and $343.4 \mathrm{~mm}$ rainfalls. In 2015 (during January-August) was recorded $19.3{ }^{\circ} \mathrm{C}$ temperature, $54.4 \%$ humidity and $156.8 \mathrm{~mm}$ rainfalls (Table 1 ). In terms of morphological and systematic soil conditions, the soil is classified as chernozem $(\mathrm{Cz})$, with an average supply of nutritive elements, $3.8 \%$ organic matter and a $\mathrm{pH}$ of 5.8 .

\section{Biological material and experimental design}

The biological material consisted of runner bean seeds (' $\mathrm{C} 3$ ' local population, with white seeds), common maize seeds ('Flato' F1 hybrid), sunflower seeds ('Tristan' F1 hybrid) and Jerusalem artichoke tubers ('Topstar' cultivar). The experiment was organized using a randomized block design with three

Table 1. Meteorological conditions of the two experimental years

\begin{tabular}{lccc}
\hline Experimental Year & $\begin{array}{c}\text { Temperature } \\
\left({ }^{\circ} \mathrm{C}\right)\end{array}$ & $\begin{array}{c}\text { Humidity } \\
(\%)\end{array}$ & $\begin{array}{c}\text { Rainfalls } \\
(\mathrm{mm})\end{array}$ \\
\hline First Year $(2014)$ & 11.9 & 70.5 & 343.4 \\
Second Year $(2015)$ & 19.3 & 54.4 & 156.8 \\
\hline
\end{tabular}

replication, where each replication was covering an area of 6 square. The studied experimental factor was the trellis system with six variants:

$(\mathrm{V} 1)=$ trellis, with double rows, on individual string,

(V2) = trellis, with a single row, on individual string,

$(\mathrm{V} 3)=$ trellis, in a single row, on synthetic net $(17 \mathrm{~cm}$ mesh $)$,

(V4) = intercropping with common maize plants,

(V5) = intercropping with sunflower plants,

(V6) = intercropping with Jerusalem artichoke plants.

On each replication plot, two rows of nests of two plants were placed, spaced at $1.0 \mathrm{~m}$, and between nests and plants, on the row, there was a distance of $0.4 \mathrm{~m}$. In the variant $\mathrm{V} 1$, the distance between the two rows on the same trellis was $0.4 \mathrm{~m}$. The distance between common maize plants, the sunflower plants and Jerusalem artichoke plants was $0.8 \mathrm{~m}$. For runner bean pure crop (V1, V2 and V3 variants), the support system consisted of a trellis composed of reinforced concrete pillars and a steel wire of $2.0 \mathrm{~mm}$ diameter, located on their upper end. The crop was established in the first part of May, when the average temperature in the soil, at 3-5 cm, has a value of 10-12 ${ }^{\circ} \mathrm{C}$, by direct sowing of three runner bean seeds per nest and two seeds per nest for common maize and respectively, sunflower. At the time of emergence, two runner bean plants and one plant of common maize or sunflower have been left in each nest. As for the Jerusalem artichoke, the tubers were planted in pairs per nests and at the emergence time only two stems per nest were allowed. Sowing of common maize and sunflower, respectively planting Jerusalem artichokes, were made about two weeks before sowing the runner bean. The experiment was conducted in accordance with technological recommendations arising from the specialized literature for runner bean and for associated plants (Popa, 2010).

\section{Assessment of experimental variants}

Experimental variants were evaluated based on observations and biometric measurements: plant phenology, assimilating pigments content, dry matter (DM), crude ash (CA), organic matter $(\mathrm{OM})$, crude protein $(\mathrm{CP})$, crude fat $(\mathrm{EE})$, crude fibre $(\mathrm{CF})$, nitrogen free extractive substances (NFES) and agro productivity.

Plant phenology was assessed by recording the main phenological phases of the crop: the period from sowing to emergence; emergence-first real trifoliate leaf; emergence-first flowers; emergence-first pods; emergence-seed maturation; emergence-end of vegetation.

Content in assimilating pigments was determined in runner bean leaves, using the spectrophotometric method, according to the protocol described by Lichtenthaler and Buschmann (2001). Leaf samples were taken from the upper third of the plant, corresponding to the area with young pods (green) in two moments: the first moment, when the plants were aged 58 days and one-two pods were formed in the upper third of the plant; the second moment, when plants had 107 days, toward the end of the vegetation period. Through the spectrophotometer, the absorbance at $661.6 \mathrm{~nm}, 644.8 \mathrm{~nm}$ and $470 \mathrm{~nm}$ was measured, which correspond, respectively, to chlorophyll $a$, chlorophyll $b$, and carotenoids. After absorbance detection, the following formulas were used to determine quantity, in $\mathrm{mg} / \mathrm{g}$ :

Chlorophyll $a:$ CHLa $=(((11.24 \times \lambda 661.6-2.04 \times \lambda 644.8)$ $\times 10) / \mathrm{M}) / 1000$; 
Chlorophyll $b:$ CHLb $=(((20.13 \times \lambda 644.8-4.19 \times$ 2661.6) $\times 10) / \mathrm{M}) / 1000$;

Carotenoids $=(((1000 \times \lambda 470-1.9 \times$ CHLa-63.14 $\times$ $\mathrm{CHLb}) / 214 \times 10) / \mathrm{M} / 1000$, where, $\mathrm{M}=$ mass of fresh plant material, $\mathrm{CHLa}=$ chlorophyll $a, \mathrm{CHLb}=$ chlorophyll $b$.

Leaf dry matter was determined gravimetrically by drying in an oven at a temperature of $105^{\circ} \mathrm{C}(\mathrm{AOAC}, 1990)$.

Agro productivity was evaluated by determination of: the number of pods per plant, number of grains per pod, number of seeds per plant, mass of one thousand seeds (MTS) and the amount of seeds per hectare $\left(\mathrm{kgha}^{-1}\right)$.

The chemical composition was determined by the official methods of the Association of Official Chemists (1990). Percent protein was calculated as $\% \mathrm{~N}^{*} 6.25$.

\section{Data processing and statistical analysis}

The statistical significance was determined by one-way analysis of variance (ANOVA) analysis. 'Duncan's Multiple Range Test', one of the multiple comparison tests, was used when the difference between groups was found to be statistically significant (Ardelean et al., 2007). The measure of statistical significance was a $\mathrm{P}$ value below $0.05(\mathrm{P}<0.05)$. The data were presented on the basis of mean \pm standard deviations

\section{Results and Discussion}

\section{Runner bean plant phenology}

Morphological and physiological plant development, marked by phenophases of plant development, was not obviously influenced by the trellis system. Regarding the phenological characterization, the period from sowing to emergence was about seven to ten days, the period from emergence to appearance of the first real trifoliate leaves was around six to seven days, the period from emergence to the first flowers was about 32-35 days, the period from emergence to the first pod was about 67-70 days, the period from emergence to seed maturation was around 115-120 days and the period from emergence to the end of the vegetation period was around 130140 days (Table 2).

Among the studied variants, runner bean plants interleaved with Jerusalem artichokes had a slight delay of one-three days for the phenophases of the vegetation period, which could be due to delay caused by shading from Jerusalem artichoke plants, as well as the higher plant densities at unit surface (10 plants/square), respectively, the shading effect, in favour of phenological processes delay, also influencing the yield (Reynolds et al., 2007). The results that were obtained in pure crop are consistent with those reported by Hadjichristodoulou (1990), Popa (2010) and Munteanu et al. (2013).

\section{Assimilatingpigments content in the runner bean leaves}

The results of the content of runner bean leaves pigments are shown in Tables 3 and 4. At first measurement, the chlorophyll $\mathrm{a} / \mathrm{b}$ ratio ranged from $2.39 \mathrm{mg} / \mathrm{g}$ f.w. at variant $\mathrm{V} 6$ to $2.76 \mathrm{mg} / \mathrm{g}$ f.w. at variant V1. It should be noted that, in the intercropping system, the plants' chlorophyll concentrations are higher than those grown in pure system. In this case, the shade contributes to increasing the concentration of chlorophyll in the leaves, as a result of an adjustment mechanism of plants to lower luminance, high levels of chlorophyll being typical for ombrophile plants. Similar results were obtained by Makus (2001) at two cultivars of Phaseolus vulgaris L., Strike and Carlo. Chlorophyll $b$ is very abundant in shaded leaves, to improve the ability of chloroplasts to capture light. However, yield components have been significantly affected by the shading in the case of runner bean interleaved with common maize and Jerusalem artichoke. At the second measurement, there has been a decrease in the

Table 2. Phenological characters for runner bean crop (number of days)

\begin{tabular}{lcccccc}
\hline Variant & $\begin{array}{c}\text { Sowing } \\
\text { (emergence) }\end{array}$ & $\begin{array}{c}\text { Emergence } \\
\text { (first real trifoliate } \\
\text { leaf) }\end{array}$ & $\begin{array}{c}\text { Emergence (first } \\
\text { flowers) }\end{array}$ & $\begin{array}{c}\text { Emergence (first } \\
\text { pods) }\end{array}$ & $\begin{array}{c}\text { Emergence (seed } \\
\text { maturation) }\end{array}$ & $\begin{array}{c}\text { Emergence (end of } \\
\text { vegetation) }\end{array}$ \\
\hline V1 & $7-10$ & $6-7$ & $32-34$ & $67-70$ & $115-120$ & $130-137$ \\
V2 & $7-10$ & $6-7$ & $32-34$ & $67-70$ & $115-120$ & $130-137$ \\
V3 & $7-10$ & $6-7$ & $32-34$ & $67-70$ & $115-120$ & $130-137$ \\
V4 & $7-10$ & $6-7$ & $32-34$ & $67-70$ & $115-120$ & $130-137$ \\
V5 & $7-10$ & $6-7$ & $32-34$ & $67-70$ & $115-120$ & $130-137$ \\
V6 & $8-10$ & $7-8$ & $32-35$ & $68-71$ & $117-121$ & $135-140$ \\
\hline
\end{tabular}

Table 3. The content of assimilating pigments at the first measurement $(\mathrm{mg} / \mathrm{g}$ f.w.)

\begin{tabular}{lccccccc}
\hline Variant & DM & CHLa & CHLb & C + X & N pigments & CHLa/CHLb & (CHLa/CHLb)/(C+X) \\
\hline V1 & 2.21 & 1.87 & 0.68 & 0.68 & 3.23 & 2.76 & 3.73 \\
V2 & 2.67 & 1.76 & 0.65 & 0.64 & 3.04 & 2.71 & 3.76 \\
V3 & 2.32 & 1.48 & 0.54 & 0.55 & 2.56 & 2.72 & 3.68 \\
V4 & 1.56 & 2.25 & 0.86 & 0.83 & 3.95 & 2.6 & 3.74 \\
V5 & 1.58 & 2.18 & 0.82 & 0.81 & 3.81 & 2.64 & 3.68 \\
V6 & 1.20 & 2.5 & 1.05 & 0.91 & 4.46 & 2.39 & 3.92 \\
Average & 1.92 & 2.00 & 0.76 & 0.73 & 3.50 & 2.63 & 3.75 \\
\hline
\end{tabular}

Note: f.w. $=$ fresh weight; $\mathrm{DM}=$ dry matter; $\mathrm{CHLa}=$ chlorophyll $\mathrm{a} ; \mathrm{CHLb}=$ chlorophyll $\mathrm{b} ; \mathrm{C}+\mathrm{X}=$ carotenes and xanthophylls 
Table 4. The content of assimilating pigments at the second measurement (mg/g f.w.)

\begin{tabular}{lccccccc}
\hline Variant & DM & CHLa & CHLb & C+X & N pigments & $\begin{array}{c}\text { CHLa/ } \\
\text { CHLb }\end{array}$ & $\begin{array}{c}\text { (CHLa/CHLb)/ } \\
(\mathrm{C}+\mathrm{X})\end{array}$ \\
\hline V1 & 19.33 & 1.04 & 0.41 & 0.36 & 1.81 & 2.51 & 3.95 \\
V2 & 17.88 & 0.95 & 0.37 & 0.31 & 1.63 & 2.59 & 4.2 \\
V3 & 18.32 & 1.09 & 0.5 & 0.39 & 1.99 & 2.2 & 4.07 \\
V4 & 20.09 & 1.15 & 0.46 & 0.41 & 2.02 & 2.51 & 3.91 \\
V5 & 15.82 & 1.1 & 0.48 & 0.37 & 1.95 & 2.37 & 4.18 \\
V6 & 17.21 & 1.43 & 0.61 & 0.49 & 2.53 & 2.35 & 4.11 \\
Average & 18.11 & 1.12 & 0.47 & 0.38 & 1.98 & 2.42 & 4.07 \\
\hline
\end{tabular}

Note: f.w. $=$ fresh weight; $\mathrm{DM}=$ dry matter; $\mathrm{CHL} a=$ chlorophyll $a$; CHL $b=$ chlorophyll $b ; \mathrm{C}+\mathrm{X}=$ carotenes and xanthophylls

concentration of chlorophyll, mainly due to the decrease of chlorophyll $a$ content, the chlorophyll $a / b$ ratio being superior to the first measurement (ranged from $2.2 \mathrm{mg} / \mathrm{g}$ f.w. at variant V3 to $2.59 \mathrm{mg} / \mathrm{g}$ f.w. at variant V2). These aspects allow us to state that the yield decrease under the influence of shading can be explained by the lack of storage organs and the reducing number of pods per plant, and not by photosynthetic activity. In this case, the source (leaves)-sink (storage organs) relationship is affected. Research by Plaut $e t$ al. (1987) showed that, in the case of sink reduction, the plant recorded a blockage of assimilates in leaves, without them being stored. Similar results were obtained in our experiment.

\section{Agroproductivity of runner bean crop}

Mass of one thousand seeds (MTS) is a very important factor to measure the yield. The quantity of seed per hectare for crop establishment is also influenced by this character. So it will be higher in variants with higher MTS (Popa, 2010).

The number of pods per plant ranged from eight at variant V6 to 17 at variant V3, with an average of 13 pods/plant. The number of seeds in pod had an average value of two-four, the lowest number of seeds in pod being recorded at variant V6 (two-three). The number of seeds per plant ranged from 35 at variant $\mathrm{V} 6$ to 66 at variant $\mathrm{V} 2$ and variant V5. MTS ranged between $976.63 \mathrm{~g}$ at variant V6 and 1,238.33 g at variant V3 (Table 5).

Similar results were obtained in studies of Sadeghi $e t$ al. (2011) and Cokkizgin et al. (2013) on common bean (P. vulgaris $\mathrm{L}$.). Previous studies have shown that the MTS of runner bean ranges from 1,080 to $1,799 \mathrm{~g}$ (Hadjichristodoulou, 1990), and from $1,108 \mathrm{~g}$ to $1,308 \mathrm{~g}$, with an average of $1,204.10 \mathrm{~g}$ (Popa, 2010). Changes in runner bean weight are due to variable genetic

Table 5. Elements of runner bean productivity

\begin{tabular}{lcccc}
\hline Variant & $\begin{array}{c}\text { No. of } \\
\text { pods/plant }\end{array}$ & $\begin{array}{c}\text { No. of } \\
\text { seeds/pod }\end{array}$ & $\begin{array}{c}\text { No. of } \\
\text { seeds/plant }\end{array}$ & MTS (g) \\
\hline V1 & 10 & $3-4$ & 46 & $1,053.13$ \\
V2 & 16 & $3-4$ & 66 & $1,089.56$ \\
V3 & 17 & $3-4$ & 53 & $1,238.33$ \\
V4 & 11 & $2-4$ & 42 & $1,070.93$ \\
V5 & 17 & $3-4$ & 66 & $1,006.46$ \\
V6 & 8 & $2-3$ & 35 & 976.63 \\
Mean & 13 & $2-4$ & 51 & $1,072.5$ \\
\hline
\end{tabular}

Note: MTS = mass of one thousand seeds potential for this character (Popa, 2010).

\section{Yield of runner bean crop}

The result of the variance analysis showed that there is no difference among the variants for both years in the significance level of 1\% (Table 6). According to the Duncan multiple group tests, variants were six different groups for both study years (Table 7). The highest yield was obtained from V2 and it was separated from the other variants in significance level of 5\%. In the first experimental year, regarding the influence of the trellis system on the runner bean yield, the highest yield was obtained at variant V2 (3,610 kg ha-1), followed by variants V5 (3,342 kg ha1), V3 (3,287 kg ha-1), V1 (2,947 kg ha-1), V4 (2,234 kg ha-1) and the lowest yield was obtained at variant V6 (1,684 kg ha-1). In the second experimental year the highest yield was obtained at variant V2 (3,170 kg ha-1) followed by variants V5 (3,104 kg ha1), V3 (2,986 kg ha-1), V1 (2,516 kg ha-1), V4 (2,018 kg ha-1) and the lowest yield was obtained at variant V6 $(1,189 \mathrm{~kg}$ ha-1). Comparing the experimental years there are very significant differences between variants, with a $\mathrm{P}$ value $<0.001$. We noticed that in pure crop system was obtained the highest yield compared with the intercropping system.

In our previous studies (Hamburdă et al., 2014), the highest yield was achieved by variant $\mathrm{V} 3\left(3,325 \mathrm{~kg} \mathrm{ha}^{-1}\right)$ and the lowest by variant V6 $\left(789 \mathrm{~kg} \mathrm{ha}^{-1}\right)$, with a mean of $2,515 \mathrm{~kg} \mathrm{ha}^{-1}$. Yield differences obtained in the current study were attributed to weather conditions, 2015 being a drought year.

\section{The chemical composition of runner bean dry seeds}

The chemical composition of runner bean dry seeds from our experiment is presented in Table 8. We noticed that variant V4 recorded the highest value of organic matter, crude fat and nitrogen free extractive substances, and the highest crude protein content was obtained from $\mathrm{V} 3$ variant and it was separated from the other variants in significance level of 5\%. The crude protein values of runner bean dry seeds are lower than other protein rich foods, such as groundnut (Arachis hypogaea L.) (56.90\%) (Conkerton, Ory, 1976) and soybean (Glycine max L.) (61.40\%) (Rackis et al., 1961). An adult man of $70 \mathrm{~kg}$ body weight requires $57 \mathrm{~g}$ protein i.e. $39.9 \mathrm{~g}$ of protein daily. This means that runner beans almost would supply the required protein, assuming complete protein absorption (Aremu et al., 2006). Aremu et al. (2010) noted that $P$. coccineus had a crude fibre content of $10.5 \%$ higher than common legumes such as cowpea (Vigna unguiculata L.) (2.6\%), Bambara groundnut (Vigna subterranea 
Table 6. Mean squares from the variance analyses of the yield of runner bean in first and second experimental year

\begin{tabular}{lcc}
\hline Source & d. f.a & Yield \\
\hline First experimental year & & \\
Blocks (B) & 2 & $5.167 \mathrm{~ns}$ \\
Variants (V) & 5 & $1655430.8^{* *}$ \\
Error & 10 & 150.167 \\
Second experimental year & & \\
Blocks (B) & 2 & $684.667^{* *}$ \\
Variants (V) & 5 & $1800698.9^{* *}$ \\
Error & 10 & 22.067 \\
\hline
\end{tabular}

Note: $\mathrm{a}=$ Degrees of freedom; $\mathrm{ns}=$ Non-significant; ${ }^{* *}=$ Significant at the $1 \%$ of probability level $(\mathrm{P}<0.01) ;{ }^{*}=$ Significant at the $5 \%$ of probability level $(\mathrm{P}<$ $0.05)$

Table 7. Yield of runner bean $(\mathrm{P}<0.05)$

\begin{tabular}{lcc}
\hline & \multicolumn{2}{c}{ Yield of runner bean $\pm \operatorname{SD}\left(\mathrm{kg} \mathrm{ha}^{-1}\right)$} \\
\cline { 2 - 3 } Variant & $\begin{array}{c}\text { First } \\
\text { Experimental } \\
\text { Year }\end{array}$ & $\begin{array}{c}\text { Second } \\
\text { Experimental } \\
\text { Year }\end{array}$ \\
\hline V1 & $2,947 \pm 14.42 \mathrm{~d}$ & $2,516 \pm 14.18 \mathrm{~d}$ \\
V2 & $3,610 \pm 13.75 \mathrm{a}$ & $3,170 \pm 14.80 \mathrm{a}$ \\
V3 & $3,287 \pm 12.12 \mathrm{c}$ & $2,986 \pm 6.08 \mathrm{c}$ \\
V4 & $2,234 \pm 9.85 \mathrm{e}$ & $2,018 \pm 14.42 \mathrm{e}$ \\
V5 & $3,342 \pm 6.24 \mathrm{~b}$ & $3,104 \pm 7.94 \mathrm{~b}$ \\
V6 & $1,684 \pm 8.72 \mathrm{f}$ & $1,189 \pm 8.19 \mathrm{f}$ \\
Average & $2,850.7$ & $2,497.2$ \\
CV (\%) & 0.43 & 0.19 \\
Pvalue & $<0.001$ & $<0.001$ \\
\hline
\end{tabular}

Note: ${ }^{*}$ Different letters indicate a significant difference of $\mathrm{P} \leq 0.05$ (Duncan test); $\mathrm{SD}=$ standard deviations; $\mathrm{CV}=$ coefficient of variation
L.) (2.1-4.1\%), pigeon pea (Cajanus cajan L.) (3.8\%) and African yambean (Sphenostylis stenocarpa) (3.5\%). Our results are consistent with those reported by Ivanov (1961) quoted by Borcean and Borcean (2003) from Popa (2010), Kay (1979) quoted by Popa (2010), Aremu et al. (2006), Aremu et al. (2010), where crude ash ranged between 3.5 and $4.2 \%$, crude protein $20.0-52.6 \%$, crude fat $1.3-7.53 \%$, crude fibre $3.1-10.5 \%$ and nitrogen free extractive substances $30.1-54.71 \%$ (Table 9).

\section{Conclusions}

The trellis system and intercropping system have an important influence on the runner bean plant phenology, assimilating pigments content in the runner bean leaves, agro productivity of runner bean crop, yield of runner bean crop and chemical composition of runner bean dry seeds (quality of the harvest). The best variant of trellis for runner bean crop was the single row trellis system on individual string and the best intercropping system was intercropping with sunflower. Runner bean crop significantly capitalizes the advantages of intercropping system, for example with maize and sunflower, ensuring a support system and a favourable microclimate for plant growth. Therefore, it is obviously that runner bean, in the ecological conditions of Romania, is a species that successfully can suit the intercropping system.

\section{Acknowledgments}

This work was supported by the European Social Fund, Human Resources Development Operational Programme 20072013, project no. POSDRU/159/1.5/S/132765.

\section{References}

Table 8. Chemical composition of the dry matter of runner bean seeds (\%)

\begin{tabular}{|c|c|c|c|c|c|c|c|}
\hline Variant & $\mathrm{DM}$ & $\mathrm{CA}$ & $\mathrm{OM}$ & $\mathrm{CP}$ & $\mathrm{EE}$ & $\mathrm{CF}$ & NFES \\
\hline V1 & $88.73 \pm 0.04$ & $4.90 \pm 0.04$ & $95.12 \pm 0.01$ & $23.46 \pm 0.16$ & $2.11 \pm 0.05$ & $5.79 \pm 0.15$ & $63.77 \pm 0.09$ \\
\hline $\mathrm{V} 2$ & $88.60 \pm 0.04$ & $5.05 \pm 0.03$ & $94.84 \pm 0.03$ & $23.40 \pm 0.32$ & $1.95 \pm 0.07$ & $5.54 \pm 0.10$ & $63.95 \pm 0.28$ \\
\hline V3 & $88.84 \pm 0.05$ & $4.82 \pm 0.06$ & $95.32 \pm 0.09$ & $25.47 \pm 0.22$ & $2.12 \pm 0.06$ & $5.63 \pm 0.15$ & $62.11 \pm 0.20$ \\
\hline V4 & $89.24 \pm 0.03$ & $5.02 \pm 0.02$ & $95.56 \pm 0.02$ & $23.08 \pm 0.46$ & $2.16 \pm 0.11$ & $5.41 \pm 0.11$ & $64.92 \pm 0.56$ \\
\hline V5 & $88.90 \pm 0.11$ & $4.97 \pm 0.05$ & $95.24 \pm 0.12$ & $23.91 \pm 0.41$ & $2.07 \pm 0.04$ & $5.81 \pm 0.06$ & $63.45 \pm 0.41$ \\
\hline V6 & $88.04 \pm 0.04$ & $5.47 \pm 0.01$ & $93.82 \pm 0.04$ & $22.65 \pm 0.25$ & $1.91 \pm 0.05$ & $5.75 \pm 0.15$ & $63.52 \pm 0.09$ \\
\hline Pvalue & $<0.001$ & $<0.001$ & $<0.001$ & $<0.001$ & $<0.01$ & $<0.05$ & $<0.001$ \\
\hline
\end{tabular}

Note: Values expressed in \% of $\mathrm{DM}^{*}$

${ }^{*}$ Results are expressed as the mean $(\mathrm{n}=3) \pm$ standard deviations $(\mathrm{SD}) ; \mathrm{DM}=$ dry matter; $\mathrm{CA}=$ crude ash; $\mathrm{OM}=$ organic matter; $\mathrm{CP}=\mathrm{crude}$ protein; $\mathrm{EE}=$ crude fat; $\mathrm{CF}=$ crude fibre; NFES = nitrogen free extractive substances.

Table 9. Chemical composition of the dry matter of runner bean seeds (\%) (Data from the scientific literature)

\begin{tabular}{lllll}
\hline CA & CP & EE & CF & NFES \\
\hline $3.5 \mathrm{a}$ & $20.0 \mathrm{a}$ & $1.5^{\mathrm{a}}$ & $3.1-4.4^{\mathrm{b}}$ & $51.99-54.71^{\mathrm{b}}$ \\
$3.3-4.2^{\mathrm{b}}$ & $21.64-26.69^{\mathrm{b}}$ & $1.3-1.9^{\mathrm{b}}$ & $4.02^{\mathrm{c}}$ & $30.1^{\mathrm{c}}$ \\
$4.1 \mathrm{c}$ & $52.6 \mathrm{c}$ & $7.53^{\mathrm{c}}$ & $10.5^{\mathrm{d}}$ & $53.1^{\mathrm{d}}$ \\
$4.6 \mathrm{~d}$ & $20.2 \mathrm{~d}$ & $7.9^{\mathrm{d}}$ & &
\end{tabular}

Note: $\mathrm{CA}=$ crude ash; $\mathrm{CP}=$ crude protein; $\mathrm{EE}=$ crude fat; $\mathrm{CF}=$ crude fibre; NFES = nitrogen free extractive substances; Different letters indicate the references: a = Kay, 1979, quoted by Popa (2010); b = Ivanov, 1961, quoted by Popa (2010); c = Aremu et al. (2006); d = Aremu et al. (2010). 
618

Anil L, Park J, Phillips RH, Miller FA (1998). Temperate intercropping of cereals for forage: A review of the potential for growth and utilization with particular reference to the UK. Grass and Forage Science 53:301317.

AOAC (1990). Official methods of analysis, 15th ed. Washington, DC: Association of Official Analytical Chemists.

Ardelean M, Sestraş R, Cordea M (2007). Horticultural experimental design (in Romanian).Ed AcademicPres, Cluj-Napoca.

Aremu MO, Olaofe O, Akintayo ET (2006). Compositional evaluation of cowpea (Vigna unguiculata) and scarlet runner bean (Phaseolus coccineus) varieties grown in Nigeria. Journal of Food, Agriculture and Environment 4(2):39-43.

Aremu MO, Olaofe O, Basu SK, Abdulazeez G, Acharya SN (2010). Processed cranberry bean (Phaseolus coccineus L.) seed flour for the African diet. Canadian Journal of PlantScience 90(5):719-728.

Butnariu G, Hamburdă SB, Teliban GC, Tălmaciu M, Munteanu N (2014). Research on entomofauna of the runner bean (Phaseolus coccineus L.) crop cultivated in intercropping system in field. Lucrări Științifice, Seria Horticultură 57(1):81-86.

Cokkizgin A, Colkesen M, Idikut L, Ozsisli B (2013). Determination of relationships between yield components in bean by using path coefficient analysis. Greener Journal of Agricultural Sciences 3(2):085089.

Conkerton EJ, Ory RL (1976). Peanut proteins as food supplements. A compositional study of selected Virginia and Spanish peanuts. Journal of the American Oil Chemists Society 53:754756.

DeAlmeida Costa GE, daSilva Queiroz-Monici K, Reis SMPM, deOliveira AC (2006). Chemical composition, dietary fibre and resistant starch contents of raw and cooked pea, common bean, chickpea and lentil legumes. Food Chemistry 94(3):327-330.

Genovese MI, Lajolo FM (2001). Inhibitory activity of trypsin of bean (Phaseolus vulgaris L.): critical evaluation of the methods of determination. Archivos Latinoamericanos de Nutricion 51(4):386394.

Hadjichristodoulou A (1990). Trials with scarlet runner beans (Phaseolus coccineous L.). Agricultural Research Institute, Ministry of Agriculture and Natural Resources.

Hamburdă SB, Dascălu T, Munteanu N (2013). Preliminary studies for new cultivation systems of runner bean (Phaseolus coccineus L.). Lucrări Științifice,Seria Horticultură 56(2):167-172.

Hamburdă SB, Munteanu N, Stoleru V, Butnariu G, Teliban GC, Popa LD (2014). Experimental results on runner bean cultivation (Phaseolus coccineus L.) in intercropping system. Lucrări Științifice, Seria Horticultură 57(1):75-80.

Hamburdă SB, Munteanu N, Teliban GC (2015). Intercropping - a Successful System for Runner Bean (Phaseolus coccineus L.) Crop. Bulletin UASVM Horticulture 72(1):81-86.

Labuda H (2010). Runner bean (Phaseolus coccineus L.) - biology and use. ActaScientiarum Polonorum, Hortorum Cultus 9(3):117-132.

Lichtenthaler HK, Buschmann C (2001). Chlorophylls and Carotenoids: Measurement and Characterization by UV-VIS Spectroscopy. Current protocols in food analytical chemistry.

Makus DJ (2001). Effect of light intensity on snap bean performance.
Subtropical Plant Science 53:19-23.

Mousavi SR, Eskandari H (2011). A general overview on intercropping and its advantages in sustainable agriculture. Journal of Applied Environmental and Biological Sciences 1(11):482-486.

Munteanu N, Hamburdă SB, Popa LD (2013). Research on the main productivity features in an assortment of runner bean (Phaseolus coccineus L.) in the environmental conditions from NE Romania. LucrăriȘtiințifice, Seria Agronomie 56(1):159-162.

Ofori F, Stern WR (1987). Cereal-legume intercropping system. Advances in Agronomy 41:41-90.

Plaut Z, Mayoral ML, Reinhold L (1987). Effect of Altered Sink: Source Ratio on Photosynthetic Metabolism of Source Leaves. Plant Physiology 85(3):786-791.

Popa LD (2010). Research on agrobiology of Phaseolus coccineus L., in order to optimize the cultivation. $\mathrm{PhD}$ Thesis (in Romanian). University of Agricultural Sciences and Veterinary Medicine Iaşi, Romania.

Rackis JJ, Anderson RL, Sesame HA, Smith AK, VanEtten CH (1961). Soybean amino acids, amino acids in soybean hulls and oil meal fractions. Journal of Agricultural and Food Chemistry 9(5):409-412.

Reynolds PE, Simpson JA, Thevathasan NV, Gordon AM (2007). Effects of tree competition on corn and soybean photosynthesis, growth, and yield in a temperate tree-based agroforestry intercropping system in southern Ontario, Canada. Ecological Engineering29(4):362-371.

Rodiňo AP, Lema EM, Marlene PB, Santalla M, De Ron AM (2007). Assessment of runner bean (Phaseolus cocineus L.) germplasm for tolerance to low temperature during early seedling growth. Euphytica 155:63-70.

Rodriguez M, Rau D, Angioi SA, Bellucci E, Bitocchi E, Nanni L, Attene G (2013). European Phaseolus coccineus L. landraces: Population Structure and Adaptation, as Revealed by cpSSRs and Phenotypic Analyses. PLoS ONE 8(2):e57337.

Santalla M, Monteagudo AB, Gonzalez AM, De Ron AM (2004). Agronomical and quality traits of runner bean germplasm and implications for breeding. Euphytica 135:205-215.

Sadeghi A, Cheghamirza K, Dorri HR (2011). The study of morphoagronomic traits relationship in common bean (Phaseolus vulgaris L.). Biharean Biologist 5(2):102-108.

Vandermeer J (1995). The ecological basis of alternative agriculture. Annual Review of Ecological Systems 26:201-224. 